\title{
Nutrition assessment and dietary guidelines: experience from the Dutch Nutrition Surveillance System
}

\author{
BY MICHIEL R. H. LÖWIK, KARIN F. A. M. HULSHOF, \\ JANTINE H. BRUSSAARD AND HENNY A. M. BRANTS \\ Department of Consumer Research and Epidemiology, TNO Nutrition and Food \\ Research Institute, PO Box 360, 3700 AJ Zeist, The Netherlands
}

The Netherlands Food and Nutrition Council (1987) recommended that the Dutch Nutrition Surveillance System should consist of two components: (1) monitoring of the Dutch population with regard to food availability and consumption and (2) a more detailed investigation into the nutritional status (and, if necessary, food consumption) of specific vulnerable groups. In 1987-8, the first Dutch National Food Consumption Survey (DNFCS) was carried out within the framework of the Dutch Nutrition Surveillance System (Löwik \& Hermus, 1988; Hulshof \& van Staveren, 1991; Löwik et al. 1994). A similar survey was carried out in 1992 (Anonymous, 1993).

Data from the surveys are used for several purposes:

(a) producing normative or reference values for characteristics of nutrition;

(b) applying the results in nutrition education;

(c) evaluating measures aimed at changing consumption patterns in population groups;

(d) assessing dietary exposure to potential harmful substances in various population groups;

(e) monitoring dietary changes over time in population groups.

The results of the data are essential for the identification of nutritional risks and for programme design and evaluation. Although the data can be used in generating and testing hypotheses, their primary purpose is related to the policy-making processes. Therefore, the policy perspective concerning the major nutrients found to be inadequate (risk nutrients) will be briefly discussed first. Summary results related to the purposes mentioned previously will be presented.

\section{POLICY PERSPECTIVE}

In 1976 The Joint Food and Agriculture Organization/United Nations International Children's Emergency Fund/World Health Organization Expert Committee (World Health Organization, 1976) published a report, Methodology of Nutritional Surveillance. The information obtained can be used to inspire decisions about food and nutrition policy issues, to predict future trends and to evaluate the effects of preventive measures. From a policy perspective it is clear that there is a need for cost-effective methods to identify groups that are nutritionally at risk. Insight into dietary patterns is the first target of nutritional surveillance, since this provides a comprehensive basis for nutritional risk assessment and nutrition education. In a later World Health Organization publication, Beghin et al. (1988) stated that nutritional assessment is justified only when taken as a preliminary step to further action.

The International Conference on Nutrition (ICN), held in Rome in 1992, adopted a 'World declaration on nutrition' and a 'Plan of action for nutrition'. In this plan one of the 
nine action-oriented themes is 'Assessing, analysing and monitoring nutrition situations'. According to this theme governments should, among other things, identify the priority nutritional problems in their country, analyse their causes, plan and implement appropriate remedial actions and monitor and evaluate efforts to improve the situation.

In general, food consumption data are used as a first step in assessing the nutritional status of a population. In addition, nutritional-status indicators should be used to provide confirmative information on low intakes and possible (biochemical) effects. Nutritionalstatus indicators reflect more objective and more long-term information on nutritionrelated health conditions. On the other hand, measuring nutritional-status indicators separately from other information will hamper the correct identification of dietary and non-dietary effects on the various nutritional-status indicators. Therefore, data on food consumption and those on nutritional status are complementary (Löwik \& Kistemaker, 1994).

When a risk factor is found to prevail in Dutch population groups it is important to investigate whether dietary factors are (partly) responsible for such an unfavourable situation. The results of such analyses indicate whether a particular risk factor is liable to modification by dietary factors, and provide a basis for preventive action such as nutrition education. For example, among the elderly, vitamin $\mathrm{B}_{6}$ was found to be a risk nutrient. For vitamin $\mathrm{B}_{6}$ status, the dietary factors correlating with (in vitro) cofactor stimulation of aspartate aminotransferase (EC 2.6.1.1) in erythrocytes (EAST-AC) were studied. A high value, indicating that the enzyme activity is restricted by a lack of coenzyme (pyridoxine), points to a marginal vitamin $\mathrm{B}_{6}$ status. EAST-AC was found to be positively associated with the intake of protein (especially of animal origin) and inversely with the intake of alcohol and vitamin $\mathrm{B}_{6}$ (Löwik et al. $1990 \mathrm{~b}, c$ ), whereas the effect of dietary fibre was negligible. Therefore, products with a relatively high vitamin $B_{6}$ :protein value would be expected to have a favourable effect on vitamin $B_{6}$ status. This ratio is high in products of vegetable origin, whereas the analyses showed that dietary fibre does not counteract this positive effect (completely). This information is needed when nutrition educators address the question of what to do to improve vitamin $\mathrm{B}_{6}$ status in a population.

\section{FRA MEWORK}

Data for the first DNFCS from 5898 subjects were collected between April 1987 and March 1988, and for the second survey among 6218 subjects in January-December 1992 (in both surveys holiday periods were excluded) by AGB-Attwood, a marketing research institute experienced in nationwide surveys. The survey was financially supported by, and carried out under the auspices of, the Ministry of Agriculture, Nature Management and Fisheries and the Ministry of Welfare, Health and Cultural Affairs. Households were selected from an existing panel. Institutionalized individuals, households with a householder aged 75 years or over, households whose members could not speak or read and/or write Dutch and children under 1 year were not eligible. Information on food intake was obtained using a $2 \mathrm{~d}$ record.

In addition to the large-scale food consumption surveys, the Dutch Nutrition Surveillance System consists of more detailed surveys among special groups. Special attention has recently been paid to the elderly and children of immigrants (Löwik \& Kistemaker, 1994). 


\section{RISK NUTRIENTS}

The results of the first DNFCS showed that the average intake of fat, especially saturated fatty acids, was high, whereas the intakes of carbohydrates (especially polysaccharides) and dietary fibre (per MJ) were low. For micronutrients, the mean intake of vitamin $\mathrm{B}_{6}$ per g protein, Fe (in boys aged 1-3 and 13-18 years, girls aged 1-3 years and women aged 10-49 years) and vitamin A (in boys 10-12 years old, girls aged 7-12 years and pregnant women) were below the recommended dietary allowances (RDA; Löwik et al. 1994). Other studies have shown that overweight and a low intake of I are prevalent as well (Deurenberg, 1990; Brug et al. 1992a,b). Policy processes vary for these nutritional risks. For fat consumption (and, thus, to a certain extent, indirectly carbohydrate, and dietary fibre consumption, and overweight) and I the policy processes are beyond the phase of problem formulation. Risks associated with the intake of vitamin $\mathrm{B}_{6}, \mathrm{Fe}$ and vitamin $\mathrm{A}$ are still in the phase of problem formulation. The implications of this for nutritional surveillance will be discussed.

\section{Fat}

The mean contribution of fat to daily energy intake, about $40 \%$ in $1987-8$, was much higher than the guideline of $30-35 \%$. Simulation studies showed what would happen to fat consumption if consumers consumed leaner varieties of the product groups contributing most to fat intake. This type of analysis can indicate the effectiveness of a successful intervention and, thus, provide a basis for the question of whether it is worth starting a particular intervention. If $43 \%$ of the products with the highest fat content were replaced with leaner varieties, the average contribution of fat to daily energy intake would be calculated to be $35 \%$; complete substitution would result in an average fat contribution of $28 \%$ (Löwik \& Kistemaker, 1994). These and other analyses have been used by the Steering Group for a Healthy Diet. This group (consisting of representatives of government, industry and nutrition education) initiates and coordinates activities aimed at the realization of guidelines for a healthy diet. Reduction of fat consumption is given the highest priority since its effect on public health is considered to be greatest among the prevailing nutritional risks. Furthermore, concentrating the public information campaign on fat allows an effective prevention strategy that may be supported by food industry and retailers. In 1991, a nationwide intervention programme, named 'Fat Watch' was launched. This campaign, concentrating its activities in March, has been executed in four consecutive years, with an extra year in 1995. The 'Fat Watch' campaigns of 1991, 1992 and 1993 have been evaluated by TNO Nutrition and Food Research Institute (Riedstra et al. 1993; Löwik et al. 1996).

\section{Iodine}

The Netherlands, in common with other countries, has a long-standing tradition concerning goitre prophylaxis. Several studies carried out after the last goitre prophylaxis measure showed that I intake was not completely adequate (Brug et al. 1992a,b; Brussaard et al. 1995). Policy processes are now in the phase of considering various alternatives to improve the situation. With regard to nutritional surveillance, simulation studies have been carried out to assess the potential effects of adding I to different food products. From these studies, it was concluded that it is possible to decrease the prevalence of low I intakes without 
a clear risk of exceeding the acceptable daily intake (ADI) for I by adding extra I to food products. In the first DNFCS among subjects of 3 years and over, prevalence of I intakes below $100 \mu \mathrm{g} \mathrm{I/d}$ was $10 \%$ in men and $21 \%$ in women. Simulated iodization of different food groups (e.g. bread) reduced prevalence by roughly 65\%. The ADI of $1 \mathrm{mg} / \mathrm{d}$ averaged over $2 \mathrm{~d}$ was not achieved by any subject. From the results it can also be concluded that subjects eating little or no bread or using uniodized bread would be at risk for a long-term low I intake (Brussaard et al. 1995).

\section{Iron}

Among boys aged 1-3 and 13-18 years, girls aged 1-3 years and women aged 10-49 years the average Fe intake was substantially below the RDA in both the first and the second DNFCS; ranging from $68 \%$ of RDA for 19-21-year-old women in the second survey to $90 \%$ for $13-15$-year-old girls in the first survey (RDA being $(\mathrm{mg} / \mathrm{d}): 1-3$ years old 7 , 13-18-year-old boys 15, 10-12-year-old girls 11, 13-15-year-old girls 12, 16-18-year-old girls 14, 19-21-year-old women 16, 21-49-year-old women 9). Since the bioavailability of $\mathrm{Fe}$ is affected by several (dietary) factors, and adaptation processes occur when Fe intake is low, the consequence for Fe status of the relatively low intake is uncertain. This means that policy processes have so far concentrated on problem formulation and, therefore, nutritional surveillance has to include the collection of information on the body's Fe status in the low-intake groups. These data were collected in a survey, carried out among adults, in which one of the potential risk groups could be studied, i.e. women $20-49$ years old. To determine the body's Fe status, various status indicators, such as ferritin, Fe and haemoglobin, were measured in blood of men and women aged 20-79 years. Low ferritin levels $(<20 \mathrm{ng} / \mathrm{ml}$ for men and women over 50 years of age and $10 \mathrm{ng} / \mathrm{ml}$ for women under 50 years of age) were not found among men aged 20-49 years but were found among $11 \%$ of those aged 50-79 years. For women, the corresponding prevalence estimates were 16 and $5 \%$ respectively (Brussaard et al. 1994). These results confirmed the food consumption data of the DNFCS, although the differences in risk were not as striking for $\mathrm{Fe}$ status indicators as those for Fe intake (as compared with the RDA for Fe).

\section{Vitamin A}

In evaluating the intake of vitamin A in the Netherlands, attention should be paid to both a low and a high intake, especially since the range of the intake distribution is rather large (Löwik et al. 1994) and the 'safety factor' between requirement and toxic intake level is estimated to be about 18 (Feron et al. 1990). In the first DNFCS it was found that median vitamin A intake was below the RDA (ranging from 0.7 to $1.0 \mathrm{mg} / \mathrm{d}$ ) for individuals aged 7 years and over. The first results of the second DNFCS even showed a substantially lower intake of vitamin A.

However, the latest results based on the most recent data on liver retinol levels indicated higher intake levels (Hulshof \& Kistemaker, 1994). The data presented refers to the assessment, based on the second DNFCS. Results will be presented for women aged 16-49 years only, since this group is of special interest due to potential congenital defects as a result of exposure to high levels of vitamin A. According to the Dutch Health Council/Netherlands Food and Nutrition Council (1994) a vitamin A intake of $7.5 \mathrm{mg}$ retinol equivalent/d is to be considered the 'no-teratogenic-effect' level. Above that level teratogenic effects cannot 
Table 1. Vitamin A intake (total and provided by liver products) among Dutch women aged 16-49 years in the second Dutch National Food Consumption Survey, 1992* (n 6218)

(Recommended dietary allowance for this group $0.80 \mathrm{mg} / \mathrm{d}$ (pregnant women $+0.20 \mathrm{mg} / \mathrm{d}$ ); the 'no-teratogenic-effect' level for vitamin A is considered to be $7.5 \mathrm{mg} / \mathrm{d}$ )

\begin{tabular}{lcc}
\hline \hline & \multicolumn{2}{c}{ Vitamin A (RE; mg/d; 2 d records) } \\
\cline { 2 - 3 } & From liver $\dagger$ & Total \\
\hline Minimum & $0 \cdot 00$ & 0.01 \\
P5 & 0.00 & 0.20 \\
P33 & 0.00 & 0.43 \\
Median & 0.00 & 0.56 \\
(Mean) & $(0.32)$ & $(0.85)$ \\
P67 & 0.00 & 0.79 \\
P95 & 1.79 & 2.33 \\
P99 & 4.97 & 5.39 \\
Maximum & 13.05 & 13.47 \\
\hline \hline
\end{tabular}

$P$, percentile; RE, retinol equivalent.

* For details, see p. 706.

$\dagger$ Based on mean vitamin A concentrations in liver (products)

be excluded. Mean daily vitamin A intake among women aged $16-49$ years was $0.85 \mathrm{mg} / \mathrm{d}$, which is higher than the RDA (see Table 1 ), whereas the median value was only $0.56 \mathrm{mg} / \mathrm{d}$.

If the maximum all-trans retinol levels found in liver (products) are used instead of the mean (median) levels, the average intake of vitamin A was $1.16 \mathrm{mg} / \mathrm{d}$, indicating the major contribution of liver (products) to vitamin A intake. This is also illustrated in Table 1, in which high values are not reached without the use of liver (products). Less than $1 \%$ had an intake of vitamin A higher than $7.5 \mathrm{mg} / \mathrm{d}$ when mean values of all-trans retinol concentrations in liver (products) were used. Using a 'worst case' scenario with maximum alltrans retinol concentrations in liver (products) and calculations based on separate days it was found that $10 \%$ exceeded an intake of $7.5 \mathrm{mg}$ vitamin $A$ on the first record day and $13 \%$ on the second record day. This 'worst case' scenario is of some relevance when every high intake, even during a short period of time $(1 \mathrm{~d})$, may cause an effect, and when (all) the all-trans retinol in liver (products) is bioavailable. The 'worst case' scenario is an overestimation of the prevalence of high intake levels during $1 \mathrm{~d}$ since maximum levels in liver (products) are used for the calculations. The chance of an intake which was too high occurring on a particular day is a combination of high consumption and high concentration, which both vary within and between subjects and between livers. With regard to the teratogenic effect of vitamin A, not all the information is yet available for unequivocal policy decisions. However, surveillance data show that the policy makers have to take different, and in some sense conflicting, considerations into account; also, that the ADI range is small for pregnant women (RDA $1 \mathrm{mg} / \mathrm{d}$; no-teratogenic effect $7.5 \mathrm{mg} / \mathrm{d}$ ) and that observed (short-term) intake levels of vitamin $\mathrm{A}$ are below as well as above this range.

\section{Vitamin $B_{6}$}

Since vitamin $\mathrm{B}_{6}$ can be considered a risk nutrient for (part of) the Dutch population and vitamin $\mathbf{B}_{6}$ might have a role in the development of cardiovascular disease, there is a 
Table 2. Mean daily intake of energy and vitamin $B_{6}$ in the Dutch population assessed using a $3 d$ record, according to age, gender and study group (risk* and control groups) $\dagger$

\begin{tabular}{|c|c|c|c|c|c|c|c|c|}
\hline \multirow{3}{*}{$\begin{array}{l}\text { Age-group } \\
\text { (years) ... } \\
\text { Study group . . }\end{array}$} & \multicolumn{4}{|c|}{ Men } & \multicolumn{4}{|c|}{ Women } \\
\hline & \multicolumn{2}{|c|}{$20-49$} & \multicolumn{2}{|c|}{$50-79$} & \multicolumn{2}{|c|}{$20-49$} & \multicolumn{2}{|c|}{$50-79$} \\
\hline & Risk & Control & Risk & Control & Risk & Control & Risk & Control \\
\hline$n$ & 36 & 75 & 36 & 75 & 36 & 75 & 36 & 75 \\
\hline Energy (MJ) & $10 \cdot 9$ & $11 \cdot 7$ & $9 \cdot 5$ & 9.9 & 7.9 & $9 \cdot 0$ & $7 \cdot 1$ & $7 \cdot 8$ \\
\hline \multicolumn{9}{|l|}{ Vitamin $B_{6}:$} \\
\hline mg & 1.66 & $2 \cdot 04$ & $1 \cdot 38$ & 1.80 & $1 \cdot 19$ & $1 \cdot 55$ & $1 \cdot 14$ & 1.49 \\
\hline $\mathrm{mg} / \mathrm{MJ}$ & $0 \cdot 16$ & 0.18 & 0.15 & $0 \cdot 18$ & $0 \cdot 15$ & 0.18 & 0.17 & 0.20 \\
\hline$\mu \mathrm{g} / \mathrm{g}$ protein & $18 \cdot 3$ & $21 \cdot 0$ & $18 \cdot 1$ & $20 \cdot 0$ & $17 \cdot 6$ & $19 \cdot 8$ & $18 \cdot 9$ & $19 \cdot 9$ \\
\hline
\end{tabular}

* Low vitamin $\mathrm{B}_{6}$ intake according to food-frequency questionnaire.

$\dagger$ For details of procedures, see p. 710 .

potential impact of marginal vitamin $\mathrm{B}_{6}$ status on public health. It was decided, therefore, to investigate the prevalence and (functional) consequences of a low vitamin $B_{6}$ intake. To this end, a concise food-frequency questionnaire was developed to classify respondents on the basis of their habitual level of intake of vitamin $\mathrm{B}_{6}$ and, thus, to allow selection of respondents with a low intake. Food consumption and the nutritional status of this lowintake group ( $n$ 144) were investigated in more detail, and compared with a random population sample ( $n 300$ ), thus providing insight into the nature, magnitude and potential consequences of a marginal intake of vitamin $\mathrm{B}_{6}$. The respondents recorded in a personal diary all foods and drinks consumed in the $3 \mathrm{~d}$ preceding physical examination. On the third day of the $3 \mathrm{~d}$ diary period $24 \mathrm{~h}$ urine was collected in which, among other variables, concentrations of 4-pyridoxic acid (which reflects recent vitamin $\mathrm{B}_{6}$ intake) and homocysteine were determined. Homocysteine levels were determined in the urine collected over the $24 \mathrm{~h}$ before and after an oral methionine dose $(0.1 \mathrm{~g}$ DL-methionine $/ \mathrm{kg}$ body weight). In the fasting blood several biochemical variables, especially those related to vitamin $\mathrm{B}_{6}$ metabolism, were determined.

In Table 2 preliminary results on the intake of vitamin $B_{6}$ are presented. Mean vitamin $\mathrm{B}_{6}$ intake (absolute and per $\mathrm{g}$ protein) was found to be lower in the risk group than in the control group, which indicated that preselection on the basis of the food-frequency questionnaire was successful. Moreover, and more importantly, the results of the 4-pyridoxic acid excretion in $24 \mathrm{~h}$ urine confirmed this, since substantially lower mean values were found in the risk group. Mean energy intake as well as mean vitamin $\mathrm{B}_{6}$ density was lower in the risk group, indicating that both the quantity and quality of the diet were responsible for the lower vitamin $\mathrm{B}_{6}$ intake. The data from this survey may be used to characterize the low-vitamin $\mathrm{B}_{6}$ group in terms of dietary and socio-demographic terms. Furthermore, the prevalence of a marginal vitamin $B_{6}$ status and its functional consequences may be assessed. More quantitative information on the risk nutrient vitamin $B_{6}$ is thus provided.

\section{SAFETY ASPECTS}

Another area of interest is related to the safety of food supply. Estimates of the intake of food contaminants were made in various population groups (Brussaard et al. 1996). The 
Table 3. Characteristics of the daily intake of intensive sweeteners ( $\mathrm{mg} / \mathrm{kg}$ body weight) identified using a 2 d record in the second Dutch National Food Consumption Survey, $1992 *$ for various user groups

\begin{tabular}{|c|c|c|c|c|c|}
\hline & $n$ & P50 & P95 & Maximum & ADI \\
\hline \multicolumn{6}{|l|}{ Aspartame } \\
\hline Total population & 6218 & 0 & 1.6 & $28 \cdot 8$ & 40 \\
\hline Users $\dagger$ & 795 & $1 \cdot 2$ & $7 \cdot 5$ & $28 \cdot 8$ & \\
\hline \multicolumn{6}{|l|}{ Cyclamate } \\
\hline Total population & 6218 & 0 & 0 & $12 \cdot 7$ & 11 \\
\hline Users $\dagger$ & 243 & 0.8 & $7 \cdot 8$ & $12 \cdot 7$ & \\
\hline \multicolumn{6}{|l|}{ Saccharin } \\
\hline Total population & 6218 & 0 & 0 & $3 \cdot 4$ & $2 \cdot 5$ \\
\hline Users ${ }^{\dagger}$ & 312 & $0 \cdot 2$ & $1 \cdot 4$ & $3 \cdot 4$ & \\
\hline \multicolumn{6}{|l|}{ Acesulfame $\mathrm{K}$} \\
\hline Total population & 6218 & 0 & 0 & $0 \cdot 5$ & 9 \\
\hline Users $†$ & 12 & $0 \cdot 1$ & $-\uparrow$ & $0 \cdot 5$ & \\
\hline
\end{tabular}

P, percentile; ADI, acceptable daily intake.

* For details, see pp. 706, 711 and 712 .

$\dagger$ During a $2 \mathrm{~d}$ period.

$\ddagger$ Not calculated due to small number of subjects.

results showed that the intakes of $\mathrm{Cd}, \mathrm{Pb}$, polychlorinated biphenols, 2,2'dichlorodiphenyltrichloroethane, hexachlorobenzene, nitrate and malathion were lower in 1987-8 than in 1976-8 and in 1984-6. Mean intake levels were well below the ADI, whereas at most, a small proportion of the population had an intake exceeding the ADI. The highest proportions were found for nitrate and for the younger age-groups. Since the starting point of an ADI is lifetime exposure, the observation of a high intake ( $2 \mathrm{~d}$ records) among young children (temporary high exposure per kg body weight) should be interpreted to a certain extent as a 'worst case' event.

In 1994, the European Union adopted three food additive directives which, among other factors, stated that member states are obliged to introduce systems to monitor the use and consumption of food additives. For this purpose, existing national food consumption surveys can be used. The possibilities for doing so, and some of the potential pitfalls are discussed elsewhere (Löwik, 1996).

Based on the DNFCS, results on intense sweeteners have already been obtained (Hulshof et al. 1995); a selection of the results is presented here (see Table 3). In a period of 4-5 years the proportion of users of diet soft drinks and table-top sweeteners has increased, especially among older adults. Total daily intake of intense sweeteners per $\mathrm{kg}$ body weight was calculated on the basis of $2 \mathrm{~d}$ records and a food-frequency method. The intake was calculated from the sweetener content of table-top sweeteners (obtained from manufacturers) and of diet soft drinks (maximum permitted levels). Among users of intense sweeteners the median daily intake of aspartame, cyclamate, saccharin and acesulfame $\mathrm{K}$ was only a small proportion of the ADI, when assessed using both the $2 \mathrm{~d}$ records and the food-frequency method. At the 95th percentile (P95), the highest intake level (for aspartame) of sweeteners was only a small proportion of the ADI. However, there were a few subjects with intakes exceeding the ADI $(2 \mathrm{~d}$ records: three for cyclamate and four for 
saccharin; food-frequency method: five for cyclamate and eleven for saccharin). The majority of these were children under 10 years, and the high intake was the result of a relatively-high consumption of diet soft drinks. Among about $80 \%$ of these children, data were collected in April-June; a temporary heat wave may have been the underlying cause, implying that intakes above the ADI are not habitual.

These observations call for several policy decisions before the risk assessment can be completed to provide definitive conclusions to be used for action, for example:

(1) what is the proportion of the population that may be accepted to exceed the ADI?

(2) is the ADI to be used as a demarcation point for safety and risk?

(3) should the calculations of percentiles be based on users only (resulting normally in a smaller sample size and, therefore, higher percentile values), or on the total population?

With regard to the last question, Table 3 illustrates the impact when the concept of users is the starting point of risk assessment regarding the intake of intense sweeteners. Percentile values are higher when based on users only. Furthermore, the number of subjects and, therefore, the proportion of the population, above P95 differs. For example, a calculation based on the total population implies that $5 \%$ of the population will have an intake equal to or above P95. For users of aspartame, cyclamate, saccharin and acesulfame $\mathrm{K}$, the proportion at or above P95 (among users) was $0.6,0.2,0.3$ and 0.01 when based on the sample size of the total population. Therefore, when calculated for users only, P95 depends not only on the intake levels but also on the proportion of users. The proportion of users depends on the method used to assess food consumption, and a shorter time period will result in a smaller proportion of users. Moreover, the consumption level among users depends on the time frame of the assessment, especially for irregularly-consumed products, in that higher intake levels will be observed in a shorter time frame (Löwik, 1996). In conclusion, when using the proportion of users as the starting point for risk assessment, one should realize that an implicit choice is made for different 'safety' margins for different substances with regard to the proportion of consumers that may not exceed a particular value.

\section{RISK GROUPS}

Risk-group identification is a major aim of nutritional surveillance since this may provide a basis for more cost-effective interventions. Several population segments have been studied both as a special group, and in the first nationwide food consumption survey (Brants et al. 1989; Hulshof et al. 1991; Löwik et al. 1992c). For absolute dietary intake levels, age, gender, health status and physical activity are the most important factors; socioeconomic factors (including household size) and therapeutic diet were most important for the qualitative aspects of the diet. However, this segmentation revealed relatively small differences, so that their relevance in terms of expected biological effect and, in turn, impact on public health is limited. Combining such factors as education level and household size resulted in greater differences between segments (Brants et al. 1989), but at the same time the groups become smaller which may prohibit the implementation of food and nutrition policies (which are not generally tailor-made to a lot of separate groups). Exceptions have to be made for children of immigrants (Meulmeester, 1988), and patients living in nursing homes (Löwik et al. 1992a,b), since these groups clearly deviated from the general population. As to the latter group, it should be noted that this category represents a relatively small segment of the Dutch population and that solutions should be individually based 
taking factors such as illness and drug usage into account, so that a general (preventive) policy cannot be formulated.

\section{The elderly as a special group}

In the past decade several surveys on both food consumption and nutritional status among elderly people have been carried out within the framework of the Dutch Nutrition Surveillance System (Löwik \& Kistemaker, 1994). Such factors as limited income, social isolation, physical disability, mental impairment and ageing processes have been suggested to make the elderly prone to a poor nutritional status as a result of an inadequate diet (Munro, 1984). In general, the elderly consume less food and, hence, have a lower intake of energy and nutrients than younger adults. Since their nutritional requirements are considered to be comparable with those of younger adults for most nutrients, intake of particular nutrients may be inadequate in old age (Munro et al. 1987). The results of the first DNFCS showed that the elderly indeed had a somewhat lower intake of energy, establishing the vulnerability of the elderly. However, although the intake of nutrients was mostly somewhat lower among the elderly than among younger adults, the intake of most nutrients was adequate (Löwik et al. 1989, 1990a). The higher mean nutrient density of the diet among the elderly, as found in the first DNFCS (Löwik et al. 1994), will have counteracted the consequences of a lower food consumption. As to the adequacy of nutrient intake, exceptions had to be made for vitamins $\mathrm{B}_{6}$ and $\mathrm{D}$. The nutritional risks identified were not the result of a lower intake, but rather were due to a low vitamin $\mathrm{B}_{6}$ :protein intake, and limited sunlight exposure respectively. The suggestion, therefore, that the elderly are vulnerable due to their lower intake levels needs to be reconsidered for apparently healthy elderly people in the Netherlands. Furthermore, the dietary associations with the prevailing risk factors, serum cholesterol, blood pressure, overweight, vitamin $\mathrm{B}_{6}$ and vitamin $\mathrm{D}$, do not argue against the current general guidelines for a healthy diet for the Dutch population. No special recommendations, therefore, seem to be needed for apparently healthy elderly in the Netherlands. It is through the generation of these data and this insight that basic premises and assumptions are tested, so that nutrition policies can be targeted at the real issues.

\section{Low- and high-intake groups}

Generally, a risk group is identified by segmenting the population into groups on the basis of relatively-stable individual characteristics such as household size and educational level. Knowledge of dietary patterns in such groups can be used in targeting intervention programmes. When policy makers are interested only in a particular dietary risk, the most straightforward analysis in relation to risk-group identification is the characterization of low- or high-intake groups. Using the data of the first DNFCS we studied the association between the intake of added mono- and disaccharides on the one hand, and the intake of energy and nutrients and socio-demographic characteristics on the other, for twenty separate age-gender groups; each group was classified into three categories (tertiles) based on their intake of added mono- and disaccharides. This association was studied because the Netherlands Food and Nutrition Council (1987) advised in their guidelines for a healthy diet that a maximum of $15-25 \%$ of daily energy intake should originate from mono- and disaccharides. A higher intake level is not recommended because of their association with 
Table 4. Distribution (percentage of total) of selected characteristics according to level $(\mathrm{g} / \mathrm{d})$ of added mono- and disaccharides in the first Dutch National Food Consumption Survey 1987-8*

\begin{tabular}{|c|c|c|c|c|c|c|c|c|}
\hline \multirow[b]{2}{*}{$\begin{array}{l}\text { Level of added } \\
\text { mono- and } \\
\text { disaccharides . . . }\end{array}$} & \multicolumn{4}{|c|}{$\operatorname{Men}(n$ 2788) } & \multicolumn{4}{|c|}{ Women (n 3110) } \\
\hline & Low & $\begin{array}{l}\text { Inter- } \\
\text { mediate }\end{array}$ & High & $\begin{array}{c}\text { Statistical } \\
\text { significance } \\
P\end{array}$ & Low & $\begin{array}{l}\text { Inter- } \\
\text { mediate }\end{array}$ & High & $\begin{array}{c}\text { Statistical } \\
\text { significance } \\
P\end{array}$ \\
\hline \multicolumn{4}{|l|}{ Region } & $<0.001$ & & & & 0.033 \\
\hline West & 36 & 33 & 32 & & 36 & 31 & 34 & \\
\hline North & 27 & 29 & 44 & & 28 & 33 & 39 & \\
\hline East & 32 & 37 & 31 & & 33 & 35 & 32 & \\
\hline South & 30 & 33 & 37 & & 32 & 34 & 35 & \\
\hline Cities & 42 & 33 & 25 & & 36 & 35 & 29 & \\
\hline \multicolumn{4}{|l|}{ Family size } & 0.023 & & & & 0.005 \\
\hline Living alone & 44 & 23 & 32 & & 39 & 34 & 27 & \\
\hline Living with family & 33 & 34 & 33 & & 32 & 33 & 34 & \\
\hline \multicolumn{4}{|c|}{ BMI (18 years and over) } & $<0.001$ & & & & $<0.001$ \\
\hline Obese & 39 & 33 & 28 & & 41 & 33 & 27 & \\
\hline Normal & 30 & 33 & 37 & & 31 & 34 & 35 & \\
\hline \multicolumn{4}{|c|}{ Education (excluding those still studying) } & 0.009 & & & & 0.006 \\
\hline Low & 30 & 34 & 37 & & 32 & 33 & 35 & \\
\hline Intermediate & 35 & 30 & 32 & & 34 & 31 & 35 & \\
\hline High & 39 & 33 & 28 & & 33 & 43 & 24 & \\
\hline \multicolumn{4}{|c|}{ Socio-economic status } & $<0.001$ & & & & 0.006 \\
\hline Low & 30 & 34 & 36 & & 32 & 33 & 35 & \\
\hline Intermediate & 34 & 33 & 32 & & 33 & 33 & 34 & \\
\hline High & 44 & 30 & 27 & & 41 & 34 & 25 & \\
\hline
\end{tabular}

* For details, see p. 713 .

the development of dental caries and the potential impact on the nutrient density of the diet.

The results of the first DNFCS (see Table 4) showed that the group with a relatively high intake of added mono- and disaccharides was characterized by a lower proportion of residents of larger cities, those with a higher level of education, those with a higher socioeconomic status and obese persons. People living alone were more likely to belong to the group with a relatively low intake of added mono- and disaccharides. The major sources of added mono- and disaccharides were sugar, soft drinks, biscuits and pastry, sweet spreads and milk-based beverages (children). For adults, especially men, sugar was the most important source, whereas among young children the sources were more diverse than those among adults. An inverse relationship was found between the intake of added mono- and disaccharides (both in $\mathrm{g} / \mathrm{d}$ and as a percentage of total energy intake) and both nutrient density and energy (\%) derived from fat (total and saturated), protein and alcohol (see Table 5 for the results among girls aged $10-12$ years).

The mean intake of $\mathrm{Fe}$, vitamin $\mathrm{A}$, thiamin, vitamin $\mathrm{B}_{6}$ and vitamin $\mathrm{C}$, especially among those aged 4-21 years, showed that a relatively high intake of mono- and disaccharides (especially as \% of total energy intake) was accompanied by a somewhat elevated risk of an inadequate intake of micronutrients. However, in these age-groups the risk for an 
Table 5. Mean daily intake of energy and nutrients among girls aged 10-12 years (n 138) in the first Dutch National Food Consumption Survey 1987-8* according to level of intake of added mono- and disaccharides (as \% of total energy intake; en \%)

(Mean values and standard deviations)

\begin{tabular}{|c|c|c|c|c|c|c|}
\hline \multirow{2}{*}{$\begin{array}{l}\text { Level of added mono- } \\
\text { and disaccharides ... } \\
\text { Nutrient }\end{array}$} & \multicolumn{2}{|c|}{ Low } & \multicolumn{2}{|c|}{ Intermediate } & \multicolumn{2}{|c|}{ High } \\
\hline & Mean & SD & Mean & $\mathrm{SD}$ & Mean & SD \\
\hline Energy (MJ) & 9.06 & $2 \cdot 10$ & 9.28 & $2 \cdot 35$ & $9 \cdot 32$ & $2 \cdot 48$ \\
\hline Protein $(\mathrm{g})$ & 73 & 17 & 67 & 18 & 60 & 17 \\
\hline Fat $(g)$ & 102 & 29 & 100 & 32 & 92 & 30 \\
\hline Water (g) & 1413 & 338 & 1403 & 306 & 1351 & 362 \\
\hline $\mathrm{Ca}(\mathrm{mg})$ & 1075 & 407 & 992 & 335 & 837 & 328 \\
\hline $\mathrm{P}(\mathrm{mg})$ & 1484 & 404 & 1351 & 344 & 1183 & 320 \\
\hline $\mathrm{K}(\mathrm{mg})$ & 3240 & 836 & 2951 & 840 & 2759 & 688 \\
\hline $\mathrm{Fe}(\mathrm{mg})$ & $10 \cdot 0$ & $3 \cdot 7$ & $9 \cdot 3$ & $3 \cdot 0$ & $9 \cdot 2$ & $2 \cdot 7$ \\
\hline Retinol (mg) & 0.75 & $0 \cdot 38$ & 0.72 & $0 \cdot 28$ & $0 \cdot 63$ & $0 \cdot 30$ \\
\hline Thiamin $(\mathrm{mg})$ & 1.00 & $0 \cdot 29$ & 0.87 & $0 \cdot 29$ & 0.78 & 0.22 \\
\hline Riboflavin (mg) & 1.62 & 0.49 & 1.48 & 0.42 & 1.27 & 0.41 \\
\hline Vitamin $B_{6}(\mu g)$ & 1298 & 353 & 1123 & 359 & 1027 & 289 \\
\hline Vitamin C (mg) & 77 & 47 & 55 & 34 & 45 & 37 \\
\hline Protein (en \%) & $13 \cdot 8$ & $2 \cdot 5$ & $12 \cdot 1$ & $2 \cdot 0$ & 10.9 & $1 \cdot 7$ \\
\hline Saturated fat (en \%) & $17 \cdot 0$ & $2 \cdot 4$ & $16 \cdot 4$ & $2 \cdot 3$ & 14.9 & $2 \cdot 1$ \\
\hline Fat (en $\%)$ & $42 \cdot 2$ & $5 \cdot 4$ & $40 \cdot 2$ & $4 \cdot 4$ & $36 \cdot 8$ & 4.9 \\
\hline Cholesterol (mg/MJ) & 28 & 9 & 27 & 10 & 22 & 10 \\
\hline Dietary fibre (g/MJ) & $2 \cdot 5$ & 0.6 & $2 \cdot 3$ & 0.5 & $2 \cdot 1$ & 0.7 \\
\hline $\mathrm{Ca}(\mathrm{mg} / \mathrm{MJ})$ & 121 & 44 & 109 & 32 & 89 & 26 \\
\hline $\mathrm{P}(\mathrm{mg} / \mathrm{MJ})$ & 166 & 37 & 148 & 29 & 128 & 20 \\
\hline $\mathrm{Fe}(\mathrm{mg} / \mathrm{MJ})$ & $1 \cdot 11$ & $0 \cdot 32$ & 1.01 & $0 \cdot 24$ & $1 \cdot 01$ & 0.22 \\
\hline $\mathrm{K}(\mathrm{mg} / \mathrm{MJ})$ & 361 & 65 & 319 & 57 & 302 & 64 \\
\hline Retinol (mg/MJ) & 0.08 & $0 \cdot 04$ & $0 \cdot 08$ & $0 \cdot 03$ & $0 \cdot 07$ & 0.05 \\
\hline Thiamin $(\mu \mathrm{g} / \mathrm{MJ})$ & 110 & 30 & 100 & 30 & 90 & 30 \\
\hline Riboflavin (mg/MJ) & $0 \cdot 18$ & $0 \cdot 05$ & $0 \cdot 16$ & $0 \cdot 04$ & $0 \cdot 14$ & 0.04 \\
\hline Vitamin $B_{6}(\mu \mathrm{g} / \mathrm{MJ})$ & 145 & 29 & 123 & 30 & 114 & 32 \\
\hline Vitamin C (mg/MJ) & $8 \cdot 4$ & $4 \cdot 4$ & $6 \cdot 0$ & $3 \cdot 6$ & $5 \cdot 0$ & $4 \cdot 2$ \\
\hline
\end{tabular}

* For details, see p. 713.

inadequate intake of micronutrients was in general primarily due to average intake levels which were low in comparison with the RDA. In these groups the already-existing risk was somewhat elevated by a relatively high consumption of added mono- and disaccharides. Besides risks, potential health benefits can result from a relatively high intake of added mono- and disaccharides, since the proportion of energy derived from fat as well as cholesterol intake per MJ were lower at higher intake levels of added mono- and disaccharides. To a certain extent policy makers have to balance these aspects. Furthermore, when the intake of some micronutrients is considered to be too low among children, policy makers have to decide whether added mono- and disaccharides are a primary concern. If so, the data show that the sources of added mono- and disaccharides are diverse, so that a nutrition education programme will be difficult; consultations with the industry about the 
possibility of changing the supply might be the option of choice. This example shows, again, the vital importance of the interaction between policy makers and surveillance.

\section{Socio-psychological factors}

In the Netherlands the 'classical' segmentation factors, such as age, socio-economic status and region, have only a small discriminative power with regard to mean values and potential health risks. However, the large variation in dietary patterns implied that other factors had to be used to identify risk groups. To this end, TNO Nutrition and Food Research Institute obtained from the respondents (heads of the households) of the second DNFCS additional information on socio-psychological variables such as nutritional knowledge and attitudes. These data can be combined with consumption data. Vitamin $\mathbf{B}_{6}$ intake will be discussed as an example.

\section{Characterization of women with a low vitamin $B_{6}$ intake}

To characterize the low-vitamin $\mathrm{B}_{6}$-intake group, the data of the female heads of the households of the second DNFCS were used. These women were first classified into three groups (tertiles) according to their estimated vitamin $B_{6}$ intake. Women with a low vitamin $B_{6}$ intake derived more energy from carbohydrates but less from protein, whereas their energy intake was lower (Table 6). The vitamin $\mathrm{B}_{6}$ intake per $\mathrm{MJ}$ and per $\mathrm{g}$ protein was lower for women with a relatively low vitamin $B_{6}$ intake. A similar observation was made in another survey, directed particularly at vitamin $\mathrm{B}_{6}$. Women with a lower vitamin $\mathrm{B}_{6}$ intake had somewhat lower nutritional knowledge, were less prepared to pay for quality, were less health-conscious (more health-apathetic), were less quality-conscious but were more curious consumers. This indicates that health considerations will be less important in motivating a change of the diet in this group, if needed. Furthermore, quality does not seem to be the driving force in their food-choice behaviour. Perhaps their stronger curiosity might be used as a vehicle to elicit a change in food consumption. A socio-psychological profiling of a risk group is also one of the building blocks of a communication strategy when questions have to be answered on how and what to do. The first results and their potential application make the use of socio-psychological factors a promising area of nutritional surveillance.

\section{CHANGES OVER TIME}

In 1992, the mean intake of energy and several nutrients differed from the observations made 4-5 years before (see Table 7); there could be a number of explanations. It can be concluded that the Dutch diet has changed substantially in the period 1987-92 and that both positive and negative changes have occurred regarding the criteria for a healthy diet. A general conclusion is that the changes in a 4-5-year time interval imply that policy-making processes based on input from older surveys may not be appropriate for the prevailing nutritional problems. The average contribution of fat (saturated and monounsaturated fatty acids) to energy intake was lower in $1992(36.9 \%)$ than in 1987-8 (40.0\%), whereas in 1992 more energy was obtained from protein and carbohydrates (polysaccharides, but not mono- and disaccharides). These differences were seen in all age-gender groups. More detailed information on fat consumption is presented in Table 8. 
Table 6. Characteristics of adult women (heads of the households) in the second Dutch National Food Consumption Survey $1992 *$ according to vitamin $B_{6}$ intake (tertiles)

\begin{tabular}{|c|c|c|c|}
\hline $\begin{array}{l}\text { Vitamin } \mathrm{B}_{6} \text { intake } \ldots \\
n \ldots\end{array}$ & $\begin{array}{l}\text { Low } \\
682\end{array}$ & $\begin{array}{l}\text { Medium } \\
672\end{array}$ & $\begin{array}{l}\text { High } \\
688\end{array}$ \\
\hline \multicolumn{4}{|l|}{ Characteristics } \\
\hline \multicolumn{4}{|l|}{ Mean values } \\
\hline Age (years) & 44 & 46 & 44 \\
\hline Body wt (kg) & 68 & 69 & 68 \\
\hline Body height (m) & 1.67 & 1.67 & $1 \cdot 68$ \\
\hline BMI $\left(\mathrm{kg} / \mathrm{m}^{2}\right)$ & $24 \cdot 4$ & $24 \cdot 8$ & $24 \cdot 4$ \\
\hline Vitamin $B_{6}: \mathrm{mg} / \mathrm{d}$ & 0.96 & $1 \cdot 39$ & $1 \cdot 89$ \\
\hline $\mathrm{mg} / \mathrm{MJ}$ & $0 \cdot 15$ & $0 \cdot 18$ & $0 \cdot 21$ \\
\hline$\mu \mathrm{g} / \mathrm{g}$ protein & $15 \cdot 9$ & $19 \cdot 1$ & $22 \cdot 2$ \\
\hline Energy $(\mathrm{MJ} / \mathrm{d})$ & $7 \cdot 0$ & $8 \cdot 1$ & $9 \cdot 5$ \\
\hline Protein (en \%) & $15 \cdot 6$ & $16 \cdot 4$ & $16 \cdot 2$ \\
\hline Fat (en $\%)$ & 37.7 & $37 \cdot 4$ & $38 \cdot 1$ \\
\hline Carbohydrates (en \%) & $44 \cdot 1$ & $43 \cdot 8$ & $43 \cdot 0$ \\
\hline Alcohol (en \%) & $2 \cdot 6$ & $2 \cdot 4$ & $2 \cdot 8$ \\
\hline \multicolumn{4}{|l|}{ Percentage of total average } \\
\hline Nutritional knowledge & 97 & 100 & 103 \\
\hline Conducts hardly any physical activity & 107 & 101 & 93 \\
\hline \multicolumn{4}{|l|}{ Standardized scores } \\
\hline Pay for quality & -0.099 & -0.005 & $0 \cdot 101$ \\
\hline Health-conscious & $-0 \cdot 114$ & $0 \cdot 103$ & 0.009 \\
\hline Health is good for me & -0.063 & 0.013 & 0.037 \\
\hline Health-apathetic & 0.075 & -0.016 & $-0 \cdot 056$ \\
\hline Body-weight-conscious & -0.037 & 0.038 & $-0 \cdot 002$ \\
\hline Curious & 0.024 & 0.023 & -0.051 \\
\hline Quality-conscious & -0.022 & $0 \cdot 010$ & 0.013 \\
\hline
\end{tabular}

en $\%, \%$ of total energy intake.

* For details, see pp. 706 and 716.

Table 8 shows that within the four most important sources of fat there was a shift towards the leaner varieties of food and that both the proportion of users and the amount of fat (of the highest-fat varieties) have changed. The change in proportion of users suggests changes in food choice. However, this change might also be the result of changes in fat content of food products. If the fat content of a sausage has changed from 260 to 240 $\mathrm{g} / \mathrm{kg}$ the product is categorized in the medium-fat group instead of the high-fat group. This may incorrectly suggest that the consumer has intentionally chosen a leaner variety, whereas in reality the 'same' product is used. A dramatic change in proportion of users (from 2 to $46 \%$ ) was observed for milk products with a fat content below $15 \mathrm{~g} / \mathrm{kg}$. The reason for this change is mainly methodological. In the first DNFCS the data of the food composition databank (1986-7 version) were given to the nearest whole number for macronutrients. The fat content of buttermilk was below $0.5 \mathrm{~g} / 100 \mathrm{~g}$ which was rounded down to zero. In the 1993 version used in the second DNFCS the fat content of buttermilk was estimated to be $0.6 \mathrm{~g} / 100 \mathrm{~g}$. Buttermilk has now been identified as a product containing fat and used in the calculation of users of fat-containing milk products. Generally, this example is an 
Table 7. Mean daily intakes of selected dietary variables as found in the first (1987-8) and the second (1992) Dutch National Food Consumption Surveys*

(Mean values and standard deviations)

\begin{tabular}{|c|c|c|c|c|}
\hline Year of survey ... & \multicolumn{2}{|c|}{$1987-8$} & \multicolumn{2}{|c|}{1992} \\
\hline No. of subjects . . & \multicolumn{2}{|c|}{5898} & \multicolumn{2}{|c|}{6218} \\
\hline \multirow[t]{2}{*}{ Age range (years) ... } & \multicolumn{2}{|c|}{$1-85$} & \multicolumn{2}{|c|}{$1-92$} \\
\hline & Mean & SD & Mean & SD \\
\hline \multicolumn{5}{|l|}{ Daily intake } \\
\hline Energy (MJ) & $9 \cdot 7$ & $3 \cdot 1$ & $9 \cdot 3$ & $3 \cdot 0$ \\
\hline Protein (g) & 76 & 24 & 81 & 27 \\
\hline Fat $(\mathrm{g})$ & 105 & 41 & 92 & 37 \\
\hline Carbohydrate (g) & 252 & 86 & 248 & 84 \\
\hline Alcohol (g) & 10 & 19 & 10 & 19 \\
\hline Cholesterol (mg) & 297 & 141 & 246 & 119 \\
\hline Dietary fibre (g) & 23 & 9 & 15 & 7 \\
\hline Water $(\mathrm{g})$ & 2057 & 699 & 2153 & 780 \\
\hline Vitamin A (mg) & 0.91 & 0.68 & 0.71 & $0 \cdot 90$ \\
\hline Thiamin (mg) & 1.06 & 0.40 & $1 \cdot 22$ & 0.76 \\
\hline Riboflavin (mg) & 1.59 & 0.57 & 1.55 & 0.59 \\
\hline Vitamin $B_{6}(\mathrm{mg})$ & $1 \cdot 33$ & 0.48 & 1.56 & 0.61 \\
\hline Vitamin C (mg) & 73 & 54 & 73 & 51 \\
\hline $\mathrm{Fe}(\mathrm{mg})$ & $11 \cdot 7$ & $4 \cdot 1$ & $11 \cdot 7$ & $4 \cdot 3$ \\
\hline $\mathrm{Ca}(\mathrm{mg})$ & 1029 & 427 & 973 & 412 \\
\hline $\mathrm{P}(\mathrm{mg})$ & 1503 & 489 & 1512 & 662 \\
\hline $\mathrm{K}(\mathrm{g})$ & 3.47 & 1.06 & 3.46 & $1 \cdot 12$ \\
\hline \multicolumn{5}{|l|}{ Percentage of daily energy } \\
\hline Protein & $13 \cdot 3$ & $3 \cdot 1$ & $15 \cdot 0$ & $3 \cdot 5$ \\
\hline \multicolumn{5}{|l|}{ Fat: } \\
\hline Total & $40 \cdot 0$ & $7 \cdot 2$ & $36 \cdot 9$ & $6 \cdot 9$ \\
\hline Saturated & $16 \cdot 5$ & $3 \cdot 4$ & $14 \cdot 1$ & $3 \cdot 3$ \\
\hline Monounsaturated & $15 \cdot 4$ & $3 \cdot 4$ & $13 \cdot 6$ & $3 \cdot 3$ \\
\hline Polyunsaturated & 6.9 & $2 \cdot 7$ & 6.8 & $2 \cdot 5$ \\
\hline \multicolumn{5}{|l|}{ Carbohydrates: } \\
\hline Total & $43 \cdot 8$ & $8 \cdot 1$ & $45 \cdot 3$ & 8.0 \\
\hline Polysaccharides & $21 \cdot 1$ & $4 \cdot 7$ & $22 \cdot 9$ & $5 \cdot 1$ \\
\hline Mono- and disaccharides & $22 \cdot 4$ & $7 \cdot 8$ & $22 \cdot 2$ & $7 \cdot 9$ \\
\hline Alcohol & $2 \cdot 8$ & $4 \cdot 9$ & $2 \cdot 8$ & $5 \cdot 1$ \\
\hline
\end{tabular}

* For details, see pp. 706 and 716.

exception. The point is, however, that simple and apparently straightforward (calculation) methods may have a substantial impact on the results.

\section{'FAT WATCH' CAMPAIGNS}

An important question is, of course, whether the changes in fat consumption can be (partly) attributed to the national 'Fat Watch' campaigns. These campaigns make up a nationwide intervention programme which was started in 1991 and executed in four consecutive years. In relation to changes with time, it should be realized that differences in results between the 
Table 8. Characteristics of the contribution of major fat sources $*$ to the fat intake in the first (1987-8) and the second (1992) Dutch National Food Consumption Surveys (DNFCS)†

\begin{tabular}{|c|c|c|c|c|c|c|c|c|}
\hline \multirow[b]{3}{*}{ Food group } & \multicolumn{4}{|c|}{ First DNFCS ( $n$ 5898) } & \multicolumn{4}{|c|}{ Second DNFCS ( $n$ 6218) } \\
\hline & \multicolumn{2}{|c|}{$\begin{array}{c}\text { Total } \\
\text { population }\end{array}$} & \multicolumn{2}{|c|}{ Users } & \multicolumn{2}{|c|}{$\begin{array}{c}\text { Total } \\
\text { population }\end{array}$} & \multicolumn{2}{|c|}{ Users } \\
\hline & $\mathrm{g} / \mathrm{d} \ddagger$ & $\% \S$ & $\% " 1$ & $\mathrm{~g} / \mathrm{d}$ q & $g / d \ddagger$ & $\% \S$ & $\% 11$ & $\mathrm{~g} / \mathrm{d}$ \\
\hline \multicolumn{9}{|l|}{ Fats and oils } \\
\hline Margarine and butter & 21 & 62 & 89 & 24 & 13 & 50 & 75 & 17 \\
\hline Low-fat margarine & 4 & 12 & 38 & 9 & 4 & 15 & 50 & 8 \\
\hline Oils and shortenings & 6 & 18 & 47 & 14 & 6 & 23 & 51 & 12 \\
\hline Savoury sauces & 3 & 9 & 35 & 7 & 3 & 12 & 45 & 6 \\
\hline Total & 34 & 100 & & & 26 & 100 & & \\
\hline \multicolumn{9}{|l|}{ Meat products ( $\mathrm{g}$ fat $/ \mathrm{kg}$ ) } \\
\hline$<150$ & 3 & 14 & 71 & 5 & 4 & 22 & 73 & 5 \\
\hline $150-250$ & 4 & 19 & 45 & 10 & 6 & 33 & 57 & 10 \\
\hline$>250$ & 14 & 67 & 75 & 18 & 8 & 44 & 63 & 13 \\
\hline Total & 21 & 100 & & & 18 & 100 & & \\
\hline \multicolumn{9}{|l|}{ Milk products ( $\mathrm{g}$ fat $/ \mathrm{kg}$ ) } \\
\hline$<15$ & 0 & 0 & 2 & 1 & 0 & 0 & 46 & 1 \\
\hline $15-30$ & 2 & 22 & 49 & 5 & 3 & 38 & 61 & 4 \\
\hline$>30$ & 7 & 78 & 83 & 9 & 5 & 62 & 75 & 7 \\
\hline Total & 9 & 100 & & & 8 & 100 & & \\
\hline \multicolumn{9}{|l|}{ Cheese (g fat/kg) } \\
\hline$<250$ & 1 & 11 & 16 & 5 & 1 & 12 & 19 & 5 \\
\hline$>250$ & 8 & 89 & 66 & 12 & 7 & 88 & 66 & 11 \\
\hline Total & 9 & 100 & & & 8 & 100 & & \\
\hline
\end{tabular}

\footnotetext{
* Calculations based on products containing fat.

$\dagger$ For details, see pp. 706 and 717 .

$\ddagger \mathrm{g}$ fat/d obtained from the food item.

$\S$ Contribution (\%) of food item to total fat obtained from the particular food group.

II Percentage of users (based on $2 \mathrm{~d}$ record).

I $\mathrm{g} \mathrm{fat} / \mathrm{d}$ obtained from the food item for users only.
}

In relation to changes with time, it should be realized that differences in results between the first and the second DNFCS may be attributable to four main reasons: changes in sociodemographic characteristics, methodological aspects, food choice and composition of food products. A major proportion of the differences may be attributed to changes in food choice, indicating the importance of regular monitoring of food consumption. Some of the differences can be attributed to the updating of the Dutch food composition databank. Such an update reflects real changes as well as changes in analytical methods.

The 'Fat Watch' campaigns may have had an effect on both the supply and demand of food products. Löwik et al. (1996) conclude that the question regarding the effect of the campaigns cannot be answered unambiguously with the first results. However, this does not exclude a contribution by 'Fat Watch' campaigns to the reduced fat intake. On the contrary, the results of the Nielsen Food Index in relation to sales figures indicate that the first cam- 
insight into the quantitative contribution of the various factors cannot be given. Nonetheless, it should be stressed that the substantially-lower fat intake is highly relevant to public health. The example of fat shows the vital importance of the DNFCS in providing information on the actual dietary intake of the Dutch population, and also that surveys do have their limitations in providing conclusive evidence.

\section{CROSS-SECTIONAL STUDIES}

In discussions on the implications of the results of the Dutch Nutrition Surveillance System it should be realized that the surveys are cross-sectional in design. A crosssectional study may introduce systematic errors in the estimation of the prevalence of low or high values due to, among other things, intra-individual variation. For instance, among elderly people hypertension was observed among $58 \%$ of the men and $68 \%$ of the women (Löwik et al. 1990a), based on single-encounter measurements. Since blood pressure tends to regress to the mean when measured serially in multiple visits (Gifford, 1987), the prevalence of hypertension has probably been overestimated. In relation to food consumption, it is well known that intra-individual variance components are generally as large as, or larger than, inter-individual variance components. The presence of intra-individual variation in food consumption estimates diminishes the possibility of identifying relationships between dietary factors and health (risks). Furthermore, in the DNFCS prevalence values relating to low and high intake levels will be overestimated, due to the phenomenon of regression to the mean, when compared with a distribution reflecting the habitual food consumption of the population. To provide insight into the intra- and inter-individual variance components, their ratios were calculated for various Dutch population groups and nutrients. Young children and older adults had mostly relatively low values for intra-:inter-individual variance components. The highest ratios were found for cholesterol, thiamin, vitamin A, vitamin $\mathrm{C}$ and haem-Fe (Löwik et al. 1994).

Another characteristic of a cross-sectional survey is that usually only low-order correlations are found, due, among other factors, to inaccurate assessment of dietary intake and nutritional status indicators. These inaccuracies are expected to weaken, rather than to produce, associations (Liu et al. 1978; Hegsted, 1989). In a cross-sectional design, it is not only the magnitude of a particular dietary factor which is meaningful but also, and perhaps even more importantly, the observation that a particular factor is positively or inversely associated with a relevant outcome variable. However, the presence of unknown confounding factors may actually result in invalid relationships. Dietary factors are a particular example, since any diet consists of a complex set of inter-related nutrients.

\section{CONCLUSIONS}

The results presented here show that the data of the Dutch Nutrition Surveillance System can be used to address many policy- and science-oriented questions. The policy orientation implies that analyses cannot be carried out in isolation, but should take account of the policy processes for which the results will be used. A continuous flow of up-to-date information on the extent and nature of prevailing nutritional problems is needed for the formulation of nutrition policy and for guidance of (intervention) programmes. It is through changes in supply and consumption of food that nutrition policies try to realize nutrition- 
oriented goals. The differences between the first and the second DNFCS indicate the importance of regular monitoring of dietary intake. Data on both food consumption and nutritional-status indicators are needed, as demonstrated by the association between dietary factors, and nutritional-status and risk factors. In relation to risk-group identification and nutrition education, inclusion of socio-psychological factors in the surveys is a promising approach. Although food consumption data from nationwide samples are the core of the Dutch Nutrition Surveillance System, it should be realized that these data do not lead to definitive conclusions relating to prevalences of deficiencies or a marginal status. For this, information from nutritional-status indicators is needed. Population groups known or found to be at nutritional risk are being studied in more detail. For instance, elderly people have been studied comprehensively. To study vulnerable groups, a new strategy (pre-selection on intake) has been implemented with a survey in which the group with a relatively-low vitamin $\mathrm{B}_{6}$ intake is oversampled.

The Dutch Nutrition Surveillance System is financially supported by the Ministries of Health, Welfare and Sports and of Agriculture, Nature Management and Fisheries.

\section{REFERENCES}

Anonymous (1993). Zo eet Nederland, 1992 - Resultaten van de voedselconsumptiepeiling 1992 (So eats the Netherlands, 1992 - Results of the National Food Consumption Survey 1992). The Hague: Voorlichtingsbureau voor de Voeding.

Beghin, I., Cap, M. \& Dujardin, B. (1988). A Guide to Nutritional Assessment. Geneva: WHO.

Brants, H. A. M., Aarnink, E. J. M., Hulshof, K. F. A. M., Kistemaker, C. \& Löwik, M. R. H. (1989). Vetconsumptie in Nederland. Deel 1: Doelgroepsegmentatie. Voedselconsumptiepeiling 1987-1988 (Fat Intake in the Netherlands. Part 1. Target Group Segmentation. National Food Consumption Survey 1987-1988). TNO Report V89.436. Zeist: TNO Nutrition and Food Research.

Brug, J., Löwik, M. R. H., Van Binsbergen, J. J., Wedel, M., Odink, J. \& Egger, R. J. (1992a). Indicators of urinary iodide excretion among adults (Dutch Nutrition Surveillance System). Annals of Nutrition and Metabolism 36, 129-134.

Brug, J., Löwik, M. R. H., Wedel, M. \& Odink, J. (1992b). Urinary iodide excretion among elderly people before and after revision of goitre prophylaxis (Dutch Nutrition Surveillance System). European Journal of Clinical Nutrition 46, 671-679.

Brussaard, J. H., Brants, H. A. M. \& Löwik, M. R. H. (1994). De ijzerstatus van volwassen Nederlanders (Iron status among Dutch adults). Microvoedingsstoffen, pp. 25-48. Den Haag: Nederlandse Vereniging voor Voedingsleer en Levensmiddelentechnologie.

Brussaard, J. H., Hulshof, K. F. A. M. \& Löwik, M. R. H. (1995). Calculated iodine intake before and after simulated iodization (Dutch Nutrition Surveillance System). Annals of Nutrition and Metabolism 39, 85-94.

Brussaard, J. H., Van Dokkum, W., De Vos, R. H., De Kort, W. L. A. M. \& Löwik, M. R. H. (1996). Dietary intake of food contaminants in the Netherlands (Dutch Nutrition Surveillance System). Food Additives and Contaminants (In the Press).

Deurenberg, P. R. M. (1990). Anthropometrie (Anthropometry). In Voedingsraad. Voedingsbericht 1990, pp. 165-172. 's-Gravenhage: SDU Uitgeverij.

Dutch Health Council/Netherlands Food and Nutrition Council (1994). Vitamine A en teratogeniteit (Vitamin A and teratogenity). The Hague: Dutch Health Council.

Feron, V. J., Van Bladeren, P. J. \& Hermus, R. J. J. (1990). A viewpoint on the extrapolation of toxicological data from animals to man. Food and Chemical Toxicology 28, 783-788.

Gifford, R. W. (1987). Myths about hypertension in the elderly. Medical Clinics of North America 71, 1003-1011.

Hegsted, D. M. (1989). Errors of measurements. Nutrition and Cancer 12, 105-107. 
Hulshof, K. F. A. M. \& Kistemaker, C. (1994). De Consumptie van Lever en Leverprodukten en de Inneming van Vitamine A bij Zwangeren en Vrouwen in de Leeftijd van 16-50 Jaar. Voedselconsumptiepeiling 1992 (Consumption of Liver and Liver Products and the Intake of Vitamin A Among Pregnant Women and Women 16-50 Years of Age. National Food Consumption Survey 1992). TNO Report V94.493. Zeist: TNO Nutrition and Food Research.

Hulshof, K. F. A. M., Kistemaker, C. \& Bouman, M. (1995). Het Gebruik van Diverse Typen Zoetstoffen Door Verschillende Bevolkingsgroepen - Voedselconsumptiepeiling 1992 (Usage of Various Types of Intensive Sweeteners Among Various Population Groups. National Food Consumption Survey 1992). TNO Report V95.301. Zeist: TNO Nutrition and Food Research Institute.

Hulshof, K. F. A. M., Löwik, M. R. H., Kok, F. J., Wedel, M., Brants, H. A. M., Hermus, R. J. J. \& Ten Hoor, F. (1991). Diet and other life-style factors in high and low socio-economic groups (Dutch Nutrition Surveillance System). European Journal of Clinical Nutrition 45, 441-450.

Hulshof, K. F. A. M. \& Van Staveren, W. A. (1991). The Dutch National Food Consumption Survey: design, methods and first results. Food Policy 16, 257-260.

Liu, K., Stamler, J., Dyer, A., McKeever, J. \& McKeever, P. (1978). Statistical methods to assess and minimize the role of intra-individual variability in obscuring the relationship between dietary lipids and serum cholesterol. Journal of Chronic Disease 31, 399-418.

Löwik, M. R. H. (1996). Possible use of food consumption surveys to estimate exposure to additives. Food Additives and Contaminants (In the Press).

Löwik, M. R. H., Brussaard, J. H., Hulshof, K. F. A. M., Kistemaker, C., Schaafsma, G., Ockhuizen, Th. \& Hermus, R. J. J. (1994). Adequacy of the diet in the Netherlands in 1987-1988 (Dutch Nutrition Surveillance System). International Journal of Food Sciences and Nutrition 45, Suppl. 1, S1-S62.

Löwik, M. R. H. \& Hermus, R. J. J. (1988). The Dutch Nutrition Surveillance System. Food Policy 13, 359-365.

Löwik, M. R. H., Hulshof, K. F. A. M., Riedstra, M., Brants, H. A. M. \& Van Wechem, S. N. (1996). High fat intake: policy implications for the Netherlands. In Implementing Dietary Guidelines [V. Wheelock, editor] London: Chapman \& Hall (In the Press).

Löwik, M. R. H. \& Kistemaker, C. (1994). Assessment of nutritional status in the Netherlands (Dutch Nutrition Surveillance System). Bibliotheca Nutritio et Dieta 51, 68-73.

Löwik, M. R. H., Schneijder, P., Hulshof, K. F. A. M., Kistemaker, C., Sleutel, L. \& Van Houten, P. (1992a). Institutionalized elderly women have lower food intake than do those living more independently (Dutch Nutrition Surveillance System). Journal of the American College of Nutrition 11, 432-440.

Löwik, M. R. H., Schrijver, J., Odink, J., Van den Berg, H., Wedel, M. \& Hermus, R. J. J. (1990a). Nutrition and aging: Nutritional status of 'apparently healthy' elderly (Dutch Nutrition Surveillance System). Journal of the American College of Nutrition 9, 18-27.

Löwik, M. R. H., Schrijver, J., Van den Berg, H., Hulshof, K. F. A. M., Wedel, M. \& Ockhuizen, Th. (1990b). Effect of dietary fiber on the vitamin B-6 status among vegetarian and non-vegetarian elderly (Dutch Nutrition Surveillance System). Journal of the American College of Nutrition 9, 241-249.

Löwik, M. R. H., Van den Berg, H., Schrijver, J., Odink, J., Wedel, M. \& Van Houten, P. (1992b). Marginal nutritional status among institutionalized elderly women as compared to those living more independently (Dutch Nutrition Surveillance System). Journal of the American College of Nutrition 11, 673-681.

Löwik, M. R. H., Van den Berg, H., Westenbrink, S., Schrijver, J., Meulmeester, J. F. \& Ockhuizen, Th. (1992c). Risk groups among elderly people in the Netherlands. A review (Dutch Nutrition Surveillance System). Age and Nutrition 3, 72-77.

Löwik, M. R. H., Van Poppel, G., Wedel, M., Van den Berg, H. \& Schrijver, J. (1990c). Dependence of vitamin B-6 status assessment on alcohol intake among elderly men and women (Dutch Nutrition Surveillance System). Journal of Nutrition 120, 1344-1351.

Löwik, M. R. H., Westenbrink, S., Hulshof, K. F. A. M., Kistemaker, C. \& Hermus, R. J. J. (1989). Nutrition and aging: Dietary intake of 'apparently healthy' elderly (Dutch Nutrition Surveillance System). Journal of the American College of Nutrition 8, 347-356.

Meulmeester, J. F. (1988). Voedingsonderzoek bij Turkse en Marokkaanse kinderen in Nederland (Nutritional Study Among Turkish and Moroccan Children in the Netherlands). Amsterdam: Koninklijk Instituut voor de Tropen.

Munro, H. N. (1984). Nutrition and the elderly: A general overview. Journal of the American College of Nutrition 3, 341-350.

Munro, H. N., Suter, P. M. \& Russell, R. M. (1987). Nutritional requirements of the elderly. Annual Review of Nutrition 7, 23-49. 
Netherlands Food and Nutrition Council (1987). Mogelijkheden tot het opzetten van een voedingspeilingssysteem in Nederland (Possibilities of setting up a nutrition surveillance system in the Netherlands). Voeding 48, 35-43.

Riedstra, M., Brug, J., Hardeman, W., Pruyn, J. F. A. \& Löwik, M. R. H. (1993). Drie jaar landelijk Let op Vet Campagne: Wat is er gebeurd? (Three years of nationwide Fat Watch Campaigns: What has happened?). Voeding 54, 4-7.

World Health Organization (1976). Methodology of Nutritional Surveillance. Report of a Joint FAO/UNICEF/WHO Expert Committee. WHO Technical Report Series no. 593. Geneva: WHO. 